\title{
Protection of Children's Rights and Access to Child Justice in Zambia: An Enigma of the Principle of State Sovereignty
}

\author{
Lewis Bwalya Chilufya \\ School of Humanities and Social Sciences, Kwame Nkrumah University, P.O. Box 80404, Kabwe-Zambia
}

\begin{abstract}
Zambia faces violation of children's rights as well as difficulties in accessing justice by children. This situation stems from interplay of various factors. Fundamentally, these include poor legislative framework, weak enforcement mechanisms for existent laws, and cultural influences which are chiefly manifested in the customary law. Consequently, several children are denied of opportunities to meaningfully live their lives and to actualize their full potentials as citizens. By building on the primary data which was collected from three Zambian rural districts and the review of appropriate literature, the article highlights lacunas in the Zambian legal framework. It also brings to the fore the practical challenges in ensuring protection of children's rights and access to justice through enforcement of child-related laws. The article concludes that the spread of human rights as an international norm is far from becoming a universal reality. The absence of appropriate national laws, low awareness about children's rights, and the lack of stakeholder's participation in the protection of these rights hinder children's protection and their access to justice in some sovereign states.
\end{abstract}

Keywords: Children, Rights, Violation, Protection, Justice, Sovereignty

DOI: $10.7176 / \mathrm{IAGS} / 76-05$

Publication date:September $30^{\text {th }} 2019$

\subsection{Introduction}

Zambia is currently grappling with the protection of the rights of children and their access to justice. Though this phenomenon has been brought on by interplay of various factors, it is apparent that the legislative framework, its enforcement and implementation has played a significant role in what has become of children's rights in the country. Besides, it is undeniably true that several children, especially those in rural areas, are missing out on the opportunities to meaningfully live their lives as well as to existentially actualize their full potentials as citizens.

This article highlights lacunas in the Zambian legal framework as well as the practical challenges in ensuring that children's rights are protected and that they have due access to justice where violations occur. To this end, it deals with pertinent national laws and international instruments to which Zambia is a party. It also addresses the processes of enforcement of the laws which are designed to promote the protection of children's rights in sampled rural districts of Zambia. In so doing, the article ultimately argues that the growth of human rights as an international norm is far from becoming a universal reality. The absence of appropriate laws, awareness in communities about children's rights, and lack of stakeholder's participation in the protection of these rights in certain sovereign states impede children's protection and their access to justice.

\subsection{The Legal Framework}

From the onset, it should be noted that Zambia has a dualistic legislative system. On the on hand, Zambia has its own national laws, and, on the other hand, it is party to some international pieces of legislation to which it has consented as an independent sovereign state.

\subsection{National Legal Framework for Protecting Children's Rights}

Zambia has enacted laws which are intended to guarantee the protection of children's and administration of justice to them. Presently, Zambia has at least 26 pieces of legislation which provide for and regulate the rights of children. Statutes of this nature are principally contained in the country's Constitution, the Education Act (2011), the Juvenile Act, the Penal Code, the Probation of Offenders Act, and the Prisons Act.

\subsubsection{Zambian Constitutional Rights}

The Zambian Constitution guarantees civil and political rights for all people, including children. Specifically, the Constitution provides for the rights of children of Zambia through the following articles:

Article 5: Birth right and citizenship of a child

Article 12: Right to Life

Article 19: Freedom of Conscience

Article 24: Protection of Young Persons from Exploitation

However, it is worthwhile to recognize that the Constitution does not recognize the particular vulnerability of children (Media Brief on Ending Child Marriages in Zambia, 2014). Quite well, Article 13 provides for the protection of the right to personal liberty, the procedure of effecting an arrest and legality of detention in 
instances where the right to personal liberty may be restricted by law. Nonetheless, this is only a general provision that is applicable to everyone. Besides, the Constitution falls short of defining a child.

\subsubsection{Key Subsidiary Provisions for the Protection of Children's Rights}

Presently, Zambia has at least 26 pieces of legislation which provide for and regulate the rights of children. This multiplicity of laws contains disparities in the definition of the age of a child. On this score, I will only highlight those with significant bearing on children's rights.

The Education Act (2011) has domesticated the United Nations Convention on the Rights of the Child (UNCRC) in relation to education. On this basis, it provided a vital legal framework for the protection of children's right to education. Indeed, the Act regulates the provision of accessible, equitable and qualitative education. However, the Act does not specify the age at which education is compulsory. On the whole, it must be further stated categorically that the government has not defined what the school-going age is as required by the law. This lack of definition leaves children, who are supposed to be in school, vulnerable to the worst forms of child labour (cf. Article 16).

The predicament of children is compounded further by the fact that the actual definition of a child in Zambia varies according to the context and legislation (Mulenga, Kamanga and OMCT, 11). For instance, in the Juvenile Act which constitutes Chapter 53 of the laws of Zambia, a juvenile is considered as a person below the age of 19 years (Juvenile Act, Cap 53, Part 1, Section 2(1), and this age group includes a 'child', that is one who below the age of 16. In marital matters, however, one has to be at least 21 years to contract marriage without the consent of a parent or guardian (The Marriage Act, Chapter 50). Notwithstanding, customary law permits one to contract marriage as long as they have attained puberty (Lindström and Salomonson, 2005). As for attribution of criminal responsibility, the Penal Code stipulates that one has to be at least 8 years (Section 14.1, Part I, Chapter 87 of the Laws of Zambia).

The Juvenile Amendment Act of Zambia (2011) deals with the protection of juveniles, and addresses the issue of juvenile delinquents. It also contains regulations on reformatories as well as provisions in relation to court proceedings involving juveniles. In its present format, the Act makes a provision for the custody and protection of juveniles in need of care; it provides for the correction of juvenile delinquents as well as matters attendant to or connected with the foregoing. However, the Act falls short of fully reflecting the goals of the UN Convention on the Rights of the Child (UNCRC) particularly in defining who as child is as earlier mentioned. Its definition is at odds with that of the UNCRC's eighteen years and below (Article 1).

Another important legal instrument is the Probation of Offenders Act which was amended by Act Number 13 of 1994 of the Laws of Zambia. This Act aims at providing for the probation of offenders as well as for matters related to such probation. The Act, for instance, provides for the establishment of probation institutions which oversee the conduct of the probationer, that is, a person placed under supervision by a probation order. It crucially stipulates "having regard to the youth, character, antecedents, home surroundings, health or mental condition of the offender, or to the nature of the offence, or to any extenuating circumstances in which the offence was committed, it is expedient to do so, the court may, instead of sentencing him, make an order, hereinafter in this Act referred to as a "probation order"... (Article 3,1 ).

The weakness of this particular Act, as evidenced by the above concept of a probation order, lies in that probation is intricately linked to punishment, not reformation. In this manner, it is estranged to the UNCRC provisions numbers 37 and 40. Besides, it does not include issues of child treatment, protection and care of the offender. Furthermore, its article 7 (3) employs the term 'conviction' in relation to a probationer who fails to conform to the probation. Conviction, in this sense, is not appropriate for a child who comes into conflict with the law as this may result in their stigmatization. Besides, conviction may engender negative psychological effects for the involved child.

Related to the Probation Act is the Prisons Act which provides for the establishment of prisons, a prison service as well as for the management and control of prisons. It also provides for the establishment of youth corrective training centres. Article 63 of the Act empowers the Minister of Home Affairs to order a transfer of a juvenile from prison to a reformatory. In article 56, it stipulates that when the child has attained the age of four years, the officer in charge, on being satisfied that there are relatives or friends of the child who are able and willing to support it, shall cause the child to be handed over to the relatives or friends, or, if he is not satisfied, shall, subject to any other written law, hand the child over to the care of such welfare authority as may be approved for the purpose by the Commissioner. This is a pro-child provision.

On the down side, however, the same article states that "the infant child of a woman prisoner may be received into the prison with its mother and may be supplied with clothing and necessaries at the public expense". Thus, this law does not fully protect the rights of circumstantial children in that the aforementioned term 'may', which has been used in relation to the care of the child, does not place an obligation on the prison administrators.

\subsection{International Legal Obligations}

Zambia's international obligations with regard to the rights of children arise from international and regional 
treaties and conventions to which it is a party. With specific reference to children, Zambia is principally party to the International Covenant on Civil and Political Rights (ICCPR), United Nations Convention on the Rights of the Child (UNCRC), the United Nations Guidelines Standard Minimum Rules for the Administration of Juvenile Justice (1983 Beijing Rules), the UN Rules for the Protection of Juveniles Deprived of their Liberty, the United Nations Guidelines for the Prevention of Juvenile Delinquency (1990 Riyadh Rules), the International Covenant on Civil and Political Rights (ICCPR), the Conventions of the International Labour Organisation (ILO)'s Declaration on Fundamental Principles and Rights at Work of 1998, and the African Charter on the Rights and Welfare of the Child (ACRWC).

Principal ones, whose status quo is summarised in the table below, include the following: Table 1. Summary of the Status Quo of Zambia's Child Rights International Obligations

\begin{tabular}{|c|c|c|c|c|c|}
\hline & $\begin{array}{c}\text { Year it entered } \\
\text { into Force }\end{array}$ & $\begin{array}{c}\text { Zambia's Year } \\
\text { of Signing }\end{array}$ & Year of Ascension & $\begin{array}{l}\text { Zambia's Year } \\
\text { of Ratification }\end{array}$ & Domes tication \\
\hline $\begin{array}{l}\text { United Nations Convention on the Rights of the Child } \\
\text { (UNCRC) }\end{array}$ & 1990 & 1990 & & 1991 & Not Yet \\
\hline $\begin{array}{l}\text { The United Nations Guidelines Standard M inimum } \\
\text { Rules for the Administration of Juvenile Justice (1983 } \\
\text { Beijing Rules) }\end{array}$ & 1983 & Non-binding & & Non-binding & Non-applicable \\
\hline $\begin{array}{l}\text { The United Nations Guidelines for the Prevention of } \\
\text { Juvenile Delinquency (1990 Riyadh Rules) }\end{array}$ & 1990 & Non-binding & & Non-binding & Non-applicable \\
\hline $\begin{array}{l}\text { The United Nations Rules for the Protection of Children } \\
\text { Deprived of their Liberty (1990) }\end{array}$ & 1990 & Non-binding & & Non-binding & Non-applicable \\
\hline $\begin{array}{l}\text { The African Charter on the Rights and Welfare of the } \\
\text { Child (ACRWC) }\end{array}$ & 1999 & 1992 & & Not Yet & Not Yet \\
\hline $\begin{array}{l}\text { The International Covenant on Civil and Political Rights } \\
\text { (ICCPR) }\end{array}$ & 1976 & Not Signed & 1984 & Not Yet & Not Yet \\
\hline $\begin{array}{l}\text { Conventions of the International Labour Organisation } \\
\text { (ILO) }\end{array}$ & 1998 & & & 1976 & Fully \\
\hline
\end{tabular}

On the whole, the UNCRC forms the backdrop against which all programmes regarding children's rights should be developed and evaluated. This is the case because it was the first binding treaty to deal exclusively with the rights of the child, and it contains comprehensive provisions relating to child justice under Article 40. It is mainly focused on the best interests of the child; its provisions promote the protection of children from all conditions that make them susceptible to abuse or violation of their rights. Its Article 19 stipulates that all states, which are party to the Convention, should take proper legislative, administrative, social and educational measures to guarantee that the child is protected from all forms of physical or mental violence, injury or abuse, neglect or negligent treatment, maltreatment or exploitation, including sexual abuse, while in the care of parent(s), legal guardian(s) or any other person who has the care of the child. Besides, it demands that parents or, as the case may be, legal guardians, have the primary responsibility for the upbringing and development of the child (Art. 18), and that every child has the right to education (Art. 28)

The United Nations Guidelines Standard Minimum Rules for the Administration of Juvenile Justice (1983 Beijing Rules) are compatible with diverse national settings and legal structures. They present standards that can be accepted to be good general principle and practice in the administration of justice for juveniles. They represent the minimum conditions which are accepted as suitable by the United Nations for the handling of juvenile offenders under any system dealing with such persons. Although they are only recommendations and not binding on member states, they capture most of the provisions contained in UNCRC.

The Riyadh rules, which Zambia adopted in 1985, complement the provisions of the Standard Minimum Rules for the Administration of Juvenile Justice. They consist of guidelines for the State to prevent juvenile delinquency while affirming that every child has basic human rights, including, in particular, access to free education. At the same time, the rules affirm the fact that though several young persons may not be in conflict with the law, they are nonetheless abandoned, neglected, abused, exposed to drug abuse, in marginal circumstances, and are in general at social risk. They thus give guidelines for the social reintegration of children at risk of being abandoned, neglected and abused.

The ACRWC, whose underlying principles are the same as those of the UNCRC, enjoins upon African state parties to consider the best interest of the child. The ACRWC deals with child justice in detailed manner under Article 17. This Article is pertinent to juvenile justice in that it embodies articles 37 and 40 of the UNCRC in terms of children's right to personal liberty. In this respect, it states that children in conflict with law should be treated with dignity and worth.

The UN Rules for the Protection of Juveniles Deprived of their Liberty operate to ensure that juvenile detainees, and offenders, are given fair treatment and receive consideration for their age. Though Zambia has not 
expressly incorporated the Rules in its legislation, their principles are evident in the Juvenile Act.

The International Covenant on Civil and Political Rights (ICCPR) demands the protection of civil and political rights for all people, children inclusively. However, since the treaty generally concerns itself with basic civil and political rights, its provisions with regard to the administration of child justice are narrow and specific. Article 10(2) (b) of the ICCPR requires the separation of accused juveniles from adults as well as a speedy adjudication of their cases. The ICCPR, in Article 14 (4), also enjoins upon states to institute trial procedures for juveniles. Accordingly, these should take into account the offender's ages and the desirability of promoting their rehabilitation. More still, the ICCPR prohibits, in Article 6(5), the death penalty as a sentence on offenders below the age of 18 years.

The Conventions of the International Labour Organisation (ILO)'s Declaration on Fundamental Principles and Rights at Work of 1998 commits member States to respect and promote principles and rights in four core categories. One of these categories, demands for the abolition and prohibition of child labour (https://www.upf.edu/gredtiss/_pdf/2013-LLRNConf_Smit.pdf 5). Like other core Conventions, this principle is binding on member States, irrespective of whether this Convention has been ratified or not. Incidentally, article 4 of the Charter stipulates that national laws may permit the employment or work of persons of 13 to 15 years of age or light work, which is:

a) Not likely to be harmful to their health or development; and

b) Not such as to prejudice their attendance at school... or their capacity to benefit from the instructions received

In line with ILO, Article 24 of the Zambian Constitution protects young people, those under the age of 15 years, from any physical, ill-treatment, cruelty or exploitation as well against any occupation or employment that can endanger their health, interfere with their education or their physical, mental and moral development. Furthermore, Zambia's Employment Act makes it an offence for the employment of children under the age of 15 years with the exception of those whose education is not impeded in any way (Article 12).

\subsection{Findings of Study}

The findings, which informed this article, can be presented better in terms of the actual status of affair regarding children's rights and the frameworkconditions - the existence or absence of specific laws - which are necessary for effective protection of children's rights.

\subsection{Prevalence of Children's Rights Violation}

The article largely builds on the primary data I collected from three rural districts of the country, namely, Chipili (Luapula Province), Katete (Eastern Province and Chisamba (Central Province) districts. Guided by prior literature review, I developed data collection tools in for of Key Informant Interview questions, Focus Group Discussion questions and an enumeration data sheet. I administered these instruments to relevant stakeholders, especially those involved in the provision of child justice, community leaders, parents or guardians and the children themselves.

Basically, the study revealed ongoing violations of children's rights in all the surveyed districts. The table below gives a synopsis of the raw data in this respect:

Table 2. Common forms of child's right violations

\begin{tabular}{|l|c|c|c|c|c|c|c|c|c|}
\hline & \multicolumn{2}{|c|}{ Chipili } & & \multicolumn{2}{c|}{ Chisamba } & & \multicolumn{2}{|c|}{ Katete } & \\
\hline & No. & $\begin{array}{c}\text { Total No. of } \\
\text { respondents }\end{array}$ & $\%$ & No. & $\begin{array}{c}\text { Total No. of } \\
\text { respondents }\end{array}$ & $\%$ & No. & $\begin{array}{l}\text { Total No. of } \\
\text { respondents }\end{array}$ & $\%$ \\
\hline Child marriage & 53 & 83 & $63.8 \%$ & 75 & 94 & $79.8 \%$ & 51 & 76 & $67.1 \%$ \\
\hline Child labour & 55 & 83 & $66.3 \%$ & 48 & 94 & $51.1 \%$ & 63 & 76 & $83 \%$ \\
\hline Defilement & 50 & 83 & $60.2 \%$ & 42 & 94 & $44.7 \%$ & 27 & 76 & $35.5 \%$ \\
\hline Child negligence & 48 & 83 & $57.8 \%$ & 19 & 94 & $20.2 \%$ & 1 & 76 & $1.3 \%$ \\
\hline Child battering & 21 & 83 & $25.3 \%$ & & & & 46 & 76 & $60.5 \%$ \\
\hline Child expos ure to pornographic materials & 1 & 83 & $1.2 \%$ & & & & & & \\
\hline physical abuse & 19 & 83 & $22.9 \%$ & 23 & 94 & $24.5 \%$ & & & \\
\hline Incest & 2 & 83 & $2.4 \%$ & 3 & 94 & $3.2 \%$ & 1 & 76 & $1.3 \%$ \\
\hline Denial of education & 34 & 83 & $41 \%$ & 4 & 94 & $4.3 \%$ & 30 & 76 & $39.5 \%$ \\
\hline
\end{tabular}


As depicted in the table above, forms of child rights violations included defilement, incest, child marriages, child labour, negligence, child battering, denial of education, exposure to pornographic materials (films and phone mobile pictures and videos), and physical torture by police when children come in conflict with the law. The most vulnerable children were in the range of 12 to 17 years old. Generally, the girl-child, children belonging to poor families and orphans, especially double-orphans, were the most vulnerable to rights violation. Irrespective of gender, lack of care or negligence mainly affected school-going children from age the age of 6 to 18 years. In certain cases, poverty led parents or guardians to leave children to fend for themselves. As a result of this abandonment, some girls took on jobs as maids to earn an income, and this in turn created fertile grounds for child pregnancies and vulnerability to other rights violations. Sexual violation mostly affected girls between 10 to 18 years.

Incidentally, in several instances of child pregnancies, the sexually abused girl- child is forced, by parents or guardians, to marry the perpetrator of abuse. The victims were sent off to go and live with the same man until he paid lobola (bride price). On the same front, majority of parents and guardians conceded that they did not normally involve children in making decision that directly affects the latter, an issue which violated the children's right to be heard and make choices. As for the boy child, neglect normally led to indulgence into mischief such as drug and alcohol abuse, and engagement in child labour.

As for child marriages, it became evident that there was interplay between cultural practices and poverty. Like child labour, this form of violence against children was committed mainly by family members who wanted to make economic gain out of dowry and other attendant endowments. Parents and guardians emerged as key drivers of this form of violence against children and are supported by traditional community settings and practices.

Knowledge of children's rights in the targeted communities portrayed a mixed picture. Of those interviewed, $66.2 \%$ of children $(28.4 \%$ girls, $37.8 \%$ boys) were able to identify at least three children's rights. As for community members (parents \& guardians), only $48 \%$ were able to identify at least three children's rights. Besides, none of the traditional and community leaders passing by laws that promote and protect children's rights.

With regard to children's right to access to justice, the study identified a total of 197 cases of violation or abuse children of children. Of these $13 \%$ of child-related cases lost at court, $30 \%$ of child-related cases were won in similar circumstances, and $12 \%$ of child-related cases withdrawn before prosecution. As will be further explained, this state of affairs was largely due to the low capacity of law enforcers, particularly the police, to enforce children's rights and related laws.

\subsection{Framework Conditions}

The application of Juvenile Act has been questionable. Whereas the Act stipulates procedure for dealing with juvenile offender, the laws of Zambia do not delimit the length of pre-trial detention. In certain cases, this means that detained children may only be tried when they are adults due to prolonged intervening periods. This delay not only denies child offenders the privilege of speedy trial, but also exposes them to various forms of abuse. Besides, the child courts, as revealed by the study, sometimes have to grapple with uncertainty about the exact age of children. Some children are illiterate and do not know their years of birth. And those who are familiar with the law at times fake their actual age.

In addition, the Juvenile Act does not categorically state the procedures for arresting a child offender. As a result of this, the police have to follow the procedures of the Criminal Procedure Code which are applicable to adults. Article 18 (1) of this Code orders that "In making an arrest, the police officer or the person making the same shall touch or confine the body of the person to be arrested, unless there is a submission to arrest by word or action." This requirement makes child offenders vulnerable to violence as they may not have the capacity to defend themselves in that the Code justifies the use of force in arresting offenders. In this regard, violence against children lies in the manner in which they are treated upon arrest and while they are in police custody or remand.

The study also established that child offenders, in some cases, are not accorded separate custody. This is contrary to what the Act demands when it stipulates that the Commissioner of Police to shall make "arrangements for preventing, as far as possible, a juvenile while detained in a police station, or while being conveyed to or from any criminal court, or while waiting before or after attendance in any criminal court, from associating with an adult (not being a relative) who is charged with an offence... (The Juvenile Act, Chapter 53 of the Laws of Zambia, No. 276, 1964, Article 58).Apparently, lack of appropriate infrastructure at police stations and terrible situations in prisons were challenging factors in many cases. Besides, it came to light during the study that probation officers are not sufficiently knowledgeable about the rights of children and befitting procedures for handling them when they commit crimes.

In article 1(2), the Act allows for the observance of customary law when it is in conformity with the interest of the juvenile. This provision is not appropriate in that its nature and interpretation denotes that children are a 
property of their parents. In this sense, the affirmation of customary law has the effect of negatively affecting the rights of children.

The research further revealed telling absence of specific courtrooms where cases involving child offenders or victims are heard. The prevalent practice was that children offenders are treated in the same way as adults. Equally, there were no shelters which child witnesses could use for protection from perpetrators of offences particularly when such a one was a guardian or parent of the child victim or child witness.

As for law enforcers, it was learnt that some of them did not feel obliged to respect and fulfil the rights of children. In some cases, police officers were aloof on issues of children's rights and regard them as a preserve of the Victims Support Unit. Their knowledge about legislation concerning the protection of children's rights was shallow, and at worst ended at the provisions of the Penal Code. More still, some were reported to have accepted bribes from perpetrators of child rights violations so that they could either falsify the evidence of rights violation or simply prevent cases from proceeding into courts.

\subsection{Implications for Protection Children's Rights}

Apparently, the causes of child rights violation in target communities were poverty, ignorance about child rights, illiteracy, sheer disregard for children's worth and cultural practices. These factors were compounded by inconsistencies in legislation, particularly with regard to the definition of a child and the disparity between statutory and customary laws. Thus, it was clear from the study that a combination of these factors results in a weak and mostly poorly coordinated redress mechanism for children. Besides, the national budgetary allocation to enhance the cognitive ability of vulnerable children and encourage school attendance has consequently been relatively insignificant (Ministry of http://www.mofnp.gov.zm/jdownloads/National\%20Budgets/Budget\%20Speeches/2016).

As noted earlier, Zambia has ratified international instruments involving children's rights. However, it has at best only partially domesticated them. With its dual legal system, it then should be borne in mind that "all the international treaties, which it ratifies, do not apply automatically as part of national law unless domesticated of internalized by an act of Parliament" (Mulenga,Kamanga and OMCT, 11). Put differently, domestic laws hold precedence as international laws are never automatically self-executing internally.

In this sense, regardless of its fundamental significance, the UNCRC has had to be domesticated by the government for it full enforcement to take effect, and things stand, it has not been fully appropriated in the state Constitution. Even though there are sectoral policies (such as the Revised National Child Policy), and strategies that have been formulated by line Ministries working with children so as to better their welfare, it remains hard to hold the government accountable for the rights of children in the absence a complete domestication of the UNCRC. Worse still, the government has not defined standard national key performance indicators to guide the implementation and monitoring of the UNCRC.

Children in Zambia continue to engage in child labour especially in agriculture and mining due to gaps in the various pieces of legislation such as the Education Act. The country's education laws only protect children who are in school from getting married. Under Zambian laws, it is illegal to marry or marry off a learner who is a child. More still, the Ministry of Labour and Social Security (MLSS) also simply conducts labour inspections in registered private institutions only. It does not conduct any inspection in unregistered institutions, as allowed by law, where child labour is more likely to be found.

Furthermore, Article 23 of the Constitution contains extensive limitation clauses. However, they do not include status, age, birth and disability as factors against which a person can be discriminated. This element has negative implications on children's rights in terms of the non-discrimination principle enshrined in the UNCRC and the ACRWC. Other than providing for the protection of children's right to privacy under Article11 (b), the Constitution does not provide for a categorical separate provision that assures the protection of children in society in general. Thus, the Constitution falls short of the standards set in the UNCRC and ACRWC. Moreover, the principles enshrined in these instruments - namely the best interests of the child, non-discrimination, right to life, survival and maximum development and participatory rights - are not specifically provided for children. It is no wonder that as of 2018, prisons held unspecified number of children who were born in prison or lived in prisons with their incarcerated mothers. Besides, there are only a paltry three reformatory school for juveniles in the entire country (Zambia Human Rights Report, 2018).

Incidentally, the Bill of Rights, which was subjected to a referendum vote in August 2016, was progressively in that it comprehensively provided for children and their rights (Amendment Act No. 2 of 2016). It recognized the particular vulnerability of children, and enjoins upon parents, wider family, society and the State to nurture, protect and educate children for the benefit of society as a whole (Article 42.1). It also stipulated, in paragraph 3 of the same article, that a "child's best interests are of paramount importance in every matter concerning the child." Nonetheless, the Zambian people did not vote for this Bill in that referendum that took place. Largely, this was not because of its content but rather due to the political mood as the referendum coincided with the presidential and general elections. Consequently, the Bill became muffled in political 
campaigns and many ordinary citizens failed to singularly understand its value.

However, for purposes and intents, it is sufficient to understand that Zambia's Constitution (Amendment Act No. 2 of 2016 Amendment Act No. 2 of 2016) contains the Bill of rights which provides for the protection of most of rights contained in the International Covenant on Civil and Political Rights (ICCPR).

\subsection{Conclusion}

It has become clear that children's rights in Zambia remain under threat, and are being widely violated. To enhance children's right to protection and access to justice, it is imperative to strengthen the legislative framework especially by harmonizing various laws. Moreover, enforcement and implementation of these laws need to be improved. To attain this, international instruments concerning children's rights will have to be fully domesticated by assimilating them into the national laws. In turn, national laws will need to be consistent with customary law, as the latter tends to be permissive of certain practices, such as child marriages, that negatively affect children rights.

Awareness levels on children's rights are relatively low among stakeholders. This is further aggravated by limited spaces to claim their rights and influence decision making on child rights and child protection. Philosophically, however, taming of international laws is impeded by the right to sovereignty which is accorded to states, and by whose force they neither recognise an internal equal nor an external superior. On the basis of this principle, States remain the final arbiter in the affairs of their territories, and this includes promotion and protection of children's rights. On this front, it is reassuring that Zambia has, through its own initiative, developed a national strategy whose goal is to reduce child marriages by $40 \%$ by 2021 . Being party to the UNCRC, Zambia is indeed obligated to take all proper measures to guarantee that children are protected from all forms of physical or mental violence, injury or abuse, neglect or negligent treatment, maltreatment or exploitation, including sexual abuse, while in the care of parent(s), legal guardian(s) or any other person who has the care of the child. However, beyond the latest effort to eradicate child marriage, Zambia has no specific initiative to fight child abuse.

\section{Reference}

Lindström, H. and Salomonson, I. (2005). Juvenile Justice in Zambia-An Evaluation of the Three Pilot Projects. Lusaka.

Mulenga, J., Kamanga M., et al. (2008) .Human Rights Situation in Zambia. Lusaka .

Zambia Human Rights Report. (2018). United States Department of State, Bureau of Democracy, Human Rights and Labour.

The Constitution of Zambia, Amendment Act No. 2 (2016).

Media Brief on Ending Child Marriages in Zambia. (2014).

The Juvenile Amendment Act of Zambia. www.parliament.gov.zm/sites/default/files/documents/acts/Juveniles\%20Act.pdf (Accessed on 26/07/20190).

Education Act of the Laws of Zambia.

www.parliament.gov.zm/sites/default/files/documents/acts/Education\%20Act.pdf (Accessed on 23/07/2019).

The Probation of Offenders Act, Chapter 93 of the Laws of Zambia, No. 276. https://zambialaws.com/principallegislation/chapter-93probation-of-offenders-act (Accessed on 31/08/2019).

The Penal Code, Cap 87 of the Laws of Zambia, www.parliament.gov.zm/sites/default/files/documents/...Penal\%20Code\%20Act.pdf (Accessed on 28/08/2019).

The Probation of Offenders Act, Cap 93 of the Laws of Zambia, No. 276.

https://zambialaws.com/principal-legislation/chapter-93probation-of-offenders-act (Accessed on 24/07/2019).

The Prisons Act, Cap 97 of the Laws of Zambia.

https://zambialaws.com/principal-legislation/chapter-97prisons-act (Accessed on 31/07/2019).

The Marriage Act, Chapter 50 of the Laws of Zambia,

https://zambialaws.com/principal-legislation/chapter-50marriage-act (Accessed on 1/08/2019).

The United Nations Convention on the Rights of the Child (UNCRC) in International Law Documents, edited by Malcom D. Evans, Blackstone Press, London 1991.

The International Covenant on Civil and Political Rights (ICCPR) in International Law Documents, edited by Malcom D. Evans, Blackstone Press, London 1991.

The Conventions of the International Labour Organisation (ILO), 1998.

The United Nations Rules for the Protection of Juveniles Deprived of their Liberty, 1990.

United Nations Guidelines for the Prevention of Juvenile Delinquency (1990 Riyadh Rules).

The African Charter on the Rights and Welfare of the Child (ACRWC), 1999.

The United Nations Guidelines Standard Minimum Rules for the Administration of Juvenile Justice (1983 
Beijing Rules).

National Assembly of Zambia, http://www.parliament.gov.zm/node/2071 (Accessed on 18/07/2019).

National Assembly of Zambia, http://www.parliament.gov.zm/node/2071 (Accessed on 8/07/2019). https://www.upf.edu/gredtiss/_pdf/2013-LLRNConf_Smit.pdf 5 (Accessed on 1/08/2019). Ministry

of

Finance,

http://www.mofnp.gov.zm/jdownloads/National\%20Budgets/Budget\%20Speeches/2016(Accessed 8/06/2019). 